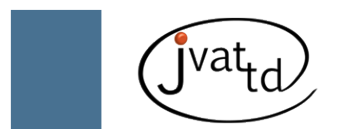

\title{
Interactions between environment, wild animals and human leptospirosis
}

\author{
Ullmann LS (1), Langoni H (2)
}

(1) Postgraduate Program in Veterinary Medicine, School of Veterinary Medicine and Animal Husbandry, São Paulo State University (UNESP - Univ Estadual Paulista), Botucatu, São Paulo State, Brazil; (2) Department of Veterinary Hygiene and Public Health, School of Veterinary Medicine and Animal Husbandry, São Paulo State University (UNESP - Univ Estadual Paulista), Botucatu, São Paulo State, Brazil.

\begin{abstract}
Leptospirosis, a worldwide distributed zoononis caused by bacteria of the genus Leptospira (antigenically classified into serovars), may be direct or indirectly transmitted through infected urine or environment. Several domestic and wild animals are leptospirosis reservoirs. The disease presents occupational character since it is widely reported in professionals that work in humid environments - such as sewage workers and fishermen - and in places where rodents or susceptible animals are found, like slaughterhouses and veterinary clinics. In developing countries, outbreaks are related to lack of sanitation, overcrowding in inadequate housing and climatic conditions. In developed countries, sporadic cases occur in aquatic recreational activities including swimming and triathlon. The diagnosis of leptospirosis is complex due to the variety of symptoms, disease severity and the lack of techniques that are able to early detect the infection. Thus, leptospirosis causes numerous public health problems and educational activities are very important to its control.
\end{abstract}

Key words: Leptospira spp., leptospirosis, public health, occupational disease, recreational disease.

\section{INTRODUCTION}

About $75 \%$ of the emerging infectious diseases that affect humans are zoonoses. The increase of human-animal interdependence may be the most critical risk factor to human health and well-being in relation to infectious diseases (1). In parallel with the ecological alterations provoked by humans in the environment, there is the exponential increase of the conflict between humans and wild animals, which leads to exposition to new infectious agents (2).

Leptospirosis is considered a worldwide zoonosis, present in all continents (except Antarctica), highlighting its importance among emerging and reemerging diseases (35). Annually, more than 500 thousand cases of severe leptospirosis are reported throughout the globe (6).
In Brazil, from 1999 to 2009, 37,035 cases of leptospirosis were notified (7). The mortality rate of Weil's disease (severe form of leptospirosis in humans) and severe hemorrhagic pulmonary syndrome (SHPS) is, respectively, above 10 and $74 \%$, which emphasizes the importance of early diagnosis to improve prognosis $(8,9)$. Some studies suggest that leptospirosis may represent 20 to $40 \%$ of febrile diseases of unknown origin (10). This prevalence is underestimated due the low medical community sensitization, absence of specific symptoms and the unavailability of diagnostic tests, besides the fact that some patients develop a mild form of the disease and do not seek for medical assistance (6).

The disease is caused by the bacterial order Spirochaetales, family Leptospiraceae, genus Leptospira (11). In 2007, taxonomy was reformulated and leptospires were divided into 
13 pathogenic species (L. alexanderi, L. alstonii, $L$. borgpetersenii, $L$. inadai, $L$. interrogans, $L$. fainei, L. kirschneri, L. licerasiae, L. noguchi, L. santarosai, L. terpstrae, L. wielli and L. wolffi) and six saprophytic ones(L. biflexa, L. meyeri, L. yanagawae, L. kmetyi, $L$. vanthielii and $L$. wolbachii) (3).

Pathogenicspeciesareclassified into serogroups composed of more than 200 serovars, based on antigenic characteristics through microscopic agglutination. Serotyping has been recognized as an essential tool in clinic and epidemiological investigations and it may indicate the reservoir involved in the disease transmission (12).

Leptospirosis can be directly transmitted through contact with secretions, blood or urine of infected animals, or indirectly through water contaminated mainly with urine of reservoir animals (13). Several domestic and wild animals get infected, thus becoming renal carriers and shedding the pathogen through their urine (14). Evidence of Leptospira spp. reservoir state has been demonstrated in all researched mammals, and this fact is a central component on the persistence and epidemiology of leptospirosis (3).

Although some serovars are associated with specific hosts, all animals are susceptible to infection by any serovar (13). Wild animals are susceptible to a wide range of Leptospira spp. serovars (15-20).

In a highly globalized world, where boundaries are continually crossed due to international tourism activities, tropical diseases including leptospirosis have emerged as significant causes of morbidity and mortality. Concerning a disease that still requires further research, it is necessary to emphasize that studies on the epidemiology and patterns of its global incidence may improve prevention practices. Leptospirosis prevention must be encouraged because outbreaks have occurred in young healthy populations, including athletes and militaries, whereas the disease urbanization is a growing concerning (21).

Globally, there have been many reports of epidemics after severe flooding (22). Due to climate changes, extreme climate events such as flooding are expected to occur with increasing frequency, potentially leading to an augment in the general incidence and frequency of leptospirosis outbreaks (23). The disease is traditionally related to socioeconomic and climatic conditions generally present in developing countries, and sporadically observed in developed countries, where the reports are commonly connected with international travels (21).

Numerous areas with a high incidence of leptospirosis are popular destinations for domestic and international travels. With the increasing popularity of ecotourism and outdoor adventure activities, travelers are likely to become increasingly exposed to leptospirosis through activities involving contact with freshwater, soil and animals (22).

In India, some behaviors of the population - including drinking stream water, walking barefoot, standing in water while working, contact with waste and keeping cows in houses - were identified as risk factors to leptospirosis (24). Having skin wounds is also a risk factor to leptospirosis (22). Stratified analysis demonstrated a dose-response relationship between the number of cattle in the house and the risk of leptospiral infection, suggesting that cattle could be one source of infection; however, the serogroups involved were Icterohaemorrhagiae and Grippotyophosa, which have rodents as reservoirs (24).

Nowadays, leptospirosis outbreaks are associated with tourism and recreational activities in wild environments $(6,25)$. Therefore, this zoonosis must be taken into account in travels, so that travelers should think about using antibiotics preventively depending on their destinations (21).

Some important variables regarding leptospirosis comprise occupational characteristics, such as local of the residence (rural or urban) and seasonal incidence of rain that reflects geographic and climatic factors. Additionally, outbreaks may occur by the interaction of three factors: the leptospiral agent, reservoir and susceptible host (15).

Factors related to occupational, environmental and recreational aspects and the presence of wild reservoirs of leptospirosis will be discussed herein.

\section{LITERATURE REVIEW}

\section{Epidemiology}

Leptospirosis is a global disease that may occur wherever the risk of direct or indirect exposure to urine or kidneys of infected animals is present (15). The central point on the epidemiology of 
leptospirosis is the state of the renal carrier, the animal that has its renal tubules colonized by leptospires, which in turn are excreted in the urine infecting the environment (3). Practically, all mammals - including aquatic ones and marsupials - have been characterized as leptospire reservoirs. Transmission occurs mainly in wet environments and not through the ingestion of food or inhalation of particles (15).

Rural habitants are always under higher risk, especially in tropical climates where they are in close contact with potentially infected domestic and wild rodents in humid conditions. In temperate climates the main sources of infection are swine, bovines and dogs (15).

Besides occupational expositions, situations related to travels and recreational activities have emerged as important routes of leptospirosis transmission (26).

The dissemination of leptospirosis in the environment depends on climatic conditions (27). In particular, zones of high rainfall and floods are frequently by severe epidemics (10). Moreover, poor sanitary conditions and inadequate rainwater drainage systems favor human contact with reservoir excretions (28).

Due to its global distribution, leptospirosis has significant impact on vulnerable populations. Slums and other places with inadequate sanitary system comprise high risk communities. The cycle of transmission of the disease is maintained because populations are continually exposed to leptospires and measures of control and surveillance are rare or inexistent (10).

\section{Occupational Aspect}

Leptospirosis affects professionals that are constantly in contact with animals and their residues, especially reservoirs $(4,29)$. The epidemiology of the disease is dynamic. New risk groups can be formed as a result of alterations in agricultural and social practices or in the reservoir population (30).

In Pelotas, Rio Grande do Sul state, a seroprevalence of $10.4 \%$ (40/386) was found in professionals who work with water supply, drains and drainage galleries, sewers, waste collection and road sweepers (31). Leptospirosis was diagnosed in one rice mill worker in the Salem district, in central Tamil Nadu, India. In rice plantations, the environment is wet, there are large rodent populations, numerous animals cohabit, and workers are exposed without protection (32). A leptospirosis seroprevalence of $25.9 \%$ (7/27) was found in Israeli troops near Jordan River and of $9.5 \%(23 / 242)$ in slaughter workers in New Zealand $(33,34)$.

In Calicut, India, leptospirosis seroprevalence was evaluated among high risk groups and the highest values was found in hospital sanitary workers (56.2\%), followed by fishermen (52.7\%), construction workers (40\%), agricultural workers $(30 \%)$, sewage workers $(28.2 \%)$, veterinarians (13.3\%) and laboratory staff (3.3\%).

In Germany, in 2007, a leptospirosis outbreak occurred among strawberry pickers. The seroprevalence was $8.5 \%(13 / 153)$ and the probable source of the infection was the contact between hand lesions and water or soil contaminated by infected voles (35).

In Guadeloupe, in the Lesser Antilles, leptospirosis occupational aspect was analyzed after a positive correlation between pluviometric index and the El Niño phenomenon in 2003. Agriculture and construction workers were the most affected professional groups (36). In Salvador, a study revealed that men of productive age showed higher seroprevalence whereas no association with occupation factor was found (28).

Risk factors for leptospirosis, brucellosis and toxoplasmosis were evaluated among students of Veterinary Medicine accordingly with the course level (residents and postgraduate students) from the São Paulo State University (UNESP), Botucatu, São Paulo state, Brazil. None of the analyzed samples reacted to leptospirosis, in spite of the constant contact between students and infected animals. Such negative results suggest that hygiene habits can contribute to leptospirosis prevention as well as the origin of the subjects, housing conditions, socioeconomic and cultural levels (37).

The analysis of 450 serum samples from blood donors of the university hospital at the Botucatu Medical School, SP, Brazil, by microscopic agglutination revealed that only six (1.33\%) were reactive, two to serovar Icterohaemorrhagiae (33.3\%) and four to serovar Pomona (66.7\%), all with titers of 100 . Analysis of epidemiological variables showed that $54.6 \%$ of the donors had contact with animals at work or their pets, mainly dogs and cats; $51.8 \%$ reported the presence of rats in their houses; $51.8 \%$ did not have the habit of 
boiling or filtering water before consumption; $39.2 \%$ had frequented ponds, streams and/or waterfalls; $18.2 \%$ did not rely on a sanitary system in their neighborhood; $8.4 \%$ did not habitually wash their hands after handling animals; 5.6\% lived in locations subject to frequent flooding and $4.2 \%$ did not habitually wash their food before consuming it. Besides the low seroprevalence, there is a need for health education for blood donors related to risks of infection, transmission and prevention of leptospirosis (38).

\section{Environmental Aspect}

Sanitation and waste disposal comprise major problems in developing countries and contribute to the incidence of several infectious diseases and other adverse health outcomes. The presence of garbage, waste and sewage promote proliferation of rodents and may increase the risk of leptospirosis, particularly in urban slums (23). Garbage might also block drainage systems and exacerbate flooding risk.

Flooding comprises the result of interactions among rainfall, run-off, catchment, sea level, and local topography that may be modified by land use, urbanization, deforestation, agricultural practices, irrigation, dams and water management (39). As a result of global climate changes, additional factors that contribute to flooding risks include rising sea levels, land surface temperatures, increasing frequency of extreme weather events, more intense tropical cyclones and larger storm surges (23). Flooding is the most common natural disaster both in developed and developing countries and is expected to occur with increasing frequency (40).

Urbanization can potentially magnify flooding intensity by tenfold. Large cities are particularly prone to flooding by the combination of large paved, compacted or roofed areas that are more impermeable than vegetated land and generate more run-off (23). Urban severe leptospirosis outbreaks occur annually in large Brazilian urban centers such as São Paulo, Rio de Janeiro, Salvador and Recife cities during heavy rain periods and are mostly associated with precarious living conditions $(12,28,41)$. Moreover, the seroprevalence of leptospirosis is inversely proportional to education level (28).

A combination of increasing flood risk, rising temperatures, poor sanitation, poor health care, poverty, abundance of rats and other reservoirs are conditions that generate high risk of leptospirosis outbreaks. These situations are more frequent in urban slums, low-living coastal areas and small island states, and their disease burden is likely to increase due to climate change, population growth and urbanization (23).

Slum residents are exposed more intensely to pathogenic leptospires. Most clinic cases occur during the rainy season due to the lack of drainage systems in poorest areas. The temporary accumulation of water is ideal for the maintenance of leptospires excreted from Rattus norvegicus urine. During the rainy season, people have frequent contact with contaminated environments by floods that bring sewage water to streets and domiciles (28). Flooding and other natural disasters may also increase the risk of infectious diseases, such as leptospirosis, by disrupting public health services and infrastructure, damaging water and sanitation networks, displacing populations, destroying homes and increasing environmental exposure to pathogens (42). This exposition can produce infections with higher concentrations of leptospires leading to more severe cases of leptospirosis (28).

In a study performed in Salvador, open sewers and rats were observed in peridomiciles where the occurrence of the severe form of leptospirosis was more frequent (43). Of the rats captured in the peridomicels of severe leptospirosis patients, more than $80 \%$ were infected with Leptospira spp., while in neighborhoods where there was no case reported of human leptospirosis, no rodents were found and these regions were more socioeconomically developed (44). It is noteworthy the importance of rodent control and basic sanitation to leptospirosis prevention. So that investment in social aspects of vulnerable communities is essential to avoid leptospirosis outbreaks (10).

Positive correlation among rainfall and leptospirosis incidence - which increased tenfold between 2002 and 2004 - was observed in Guadalupe, French Antilles Island. In 2002, El Niño phenomenon occurred twice more intensely in this area (36). The El Niño is a cyclic break in atmospheric/oceanic system in tropical Pacific area that increases rainfall and its effects can last more than 18 months (45). Besides the main risk factors related to males, occupational exposition and contact with bovine and swine 
populations, there is also the risk associated with rodents. Icterohaemorrhagiae and Ballum serogroups were the most prevalent (respectively, 62 and 36\%), and the severe form of the disease was less reported. Data suggest that alterations in leptospirosis characteristics may be related to uncommon meteorological events and their consequences on rodent population. Control of rodents and analysis of climate data were proposed as tools to leptospirosis management in Guadalupe (36).

Most leptospirosis studies are restricted to traditional risk groups. Little information is available about infection seroprevalence and pathogenic leptospires circulation among general urban population. The identification of factors that comprise the leptospirosis dynamics in humans may contribute to the knowledge of its epidemiology in urban environments, supporting its control as an emergent health problem (28).

Even after the control of environmental factors related to the occurrence of leptospirosis in slums, the socioeconomic variable contributes to the infection risk, which indicates that effective prevention of leptospirosis must encompass social factors including health services to slum communities and improvement of sanitary conditions (46).

\section{Wild animal aspect}

Wild animals are relevant in leptospirosis epidemiology since some species, mainly small mammals, act as reservoirs of many serovars (47). Several techniques can be used to leptospirosis diagnosis in wild animals, but to establish if an animal that presented titers or had positive result by molecular techniques is a pathogenic leptospire reservoir, other studies are required.

In Peru, wild mammals were captured near Iquitos to verify their potential as pathogenic leptospires reservoir. Renal tissue samples were submitted to polymerase chain reaction (PCR) and 29\% (40/136) showed renal Leptospira spp. infection evidence being 20\% (13/64) rodents, $39 \%(20 / 51)$ marsupials and 35\% (7/20) bats. Marsupials and bats appeared to be the more important reservoirs than previously recognized (48). Sera samples of 109 wild mammals living near residences were evaluated regarding the presence of Leptospira spp. antibodies. Serovars found were Icterohaemorrhagiae, Gryppothiphosa and Canicola and only samples from two opossums were not reagent. Data revealed the importance of wild animals that inhabit urban centers and can act as leptospires reservoirs to human and dogs (49).

Samples of 17 pampas deer (Ozotocerus bezoarticus) from Pantanal Mato-grossense, state of Mato Grosso do Sul, Brazil, and 24 specimens from Emas National Park, state of Goiás, were tested for the presence of Leptospira spp. antibodies. No animal from Emas National Park reacted, while four animals (24\%) captured in Pantanal region reacted to Hardjo, Wolffi and Mini serovars. Leptospirosis does not appear to present sanitary importance to these animals, but deer may act as reservoirs in one of the studied areas (50). Serology only does not indicate the animal as a leptospiral reservoir, even because the serovars found have bovines as reservoirs and they share the same habitat.

Armadillos are used as food mainly in rural areas of Brazil and little is known about their potential as source of leptospiral infection to humans and other animals. Leptospirosis seroprevalence was found in three of 31 (9.68\%) nine-banded armadillos (Dasypus novemcinctus) and one out of three (33.33\%) six-banded armadillos (Euphractus sexcinctus), demonstrating the potential risk of transmission to humans, mainly due to consumption of armadillo meat. Samples from two naked-tailed armadillos (Cabassous tatouay) and two longnosed armadillos (D. hybridus) were also tested but they did not react (17).

Boars were identified as leptospires reservoirs in numerous areas of Japan, where special attention is given to the risk of infection by hunters, butchers and hunting dogs (51). In São Paulo state, Brazil, 63 out of 308 (20.54\%) boars raised were reagent, which indicates that these captive animals can represent a source of infection to humans and other animals (20).

In Asturias, northern Spain, the presence of antibodies against Leptospira spp. was detected in deer (Cervus elaphus hispanicus and Dama dama) and boars (Sus scrofa) (52). In Germany, in boars in which serology was associated with chronic interstitial nephritis, renal tissue detection of leptospires turned them into important source of human leptospirosis in urban environment (53). In Australia, leptospiral antibodies were found gray kangaroo (Macropus giganteus) and the importance of these animals as reservoirs is still in discussion (54). 
In an experimental study, capybaras were inoculated with Pomona serovar to investigate seroconversion, leptospiremia and the reservoir potential of these animals. Shedding of leptospires in urine was detected by molecular methods between nine and 43 days after infection. Due to the intermittency, the shedding period could be longer. Capybaras can act as source of infection of leptospirosis to other animals and humans when in the same habitat (55). In a serological study of serum samples from 55 capybaras from commercial and experimental breeding facilities located in Guararapes and Piracicaba (São Paulo state), Curitiba and Foz do Iguaçu (Paraná state) and Sapucaia do Sul (Rio Grande do Sul state), Brazil, 23 samples (41.83\%) were reagent whereas regarding tested serovars, the most prevalent was Icterohaemorrhagiae (23.64\%) in 12 samples from Sapucaia do Sul and one from Guararapes, followed by Copenhageni (16.37\%), Pomona (7.28\%), Djasiman and Castellonis (5.46\%), Gryppotiphosa, Hardjo, Canicola and Cynopteri (3.64\%), Andamanda and Bratislava (1.82\%). Obtained titers were not higher than 400 and the most frequent titer was 100 (56).

Samples from 201 wild and domestic carnivores from protected areas of Andalusia, Spain, were tested to the presence of Leptospira spp. antibodies, showing a seroprevalence of $23.5 \%$ and different titers to various serovars, both in domestic and wild animals (47).

In Foz do Iguaçu, Paraná state, Brazil, one ocelot (Leopardus pardalis) and one margay (Leopardis wiedii) were seropositive to leptospirosis among 57 neotropical felids kept in captivity at the Bela Vista Biological Refuge. The seroprevalence was $3.5 \%$ (2.57) and indicates that neotropical felids have no importance in leptospirosis epidemiology (16). The presence of antibodies against Leptospira spp. in coatis (Nasua nasua) kept in captivity was studied, resulting in 52.94\% (9/17) seropositivity and showing that Copenhageni and Shermani were the most prevalent serovars. The results reveal the infection in asymptomatic animals and reinforce that wild captive animals may be infected and become reservoirs (19).

An outbreak of severe leptospirosis occurred in 52 capuchins (Cebus albifrons, C. capuchins and $C$. apella) rescued from houses and kept in a wild animal rehabilitation center in Colombia. Sixteen cases were confirmed whereas the mortality rate reached $27 \%(14 / 52)$. At necropsy, jaundice and lung hemorrhage were found. Rats were indicated as the source of infection. Animals spend at least three months in the rehabilitation center before the outbreak, which indicates that the infection was acquired at the institution in outdoor common enclosures (57). Human contact with non-human primates may create new leptospirosis reservoirs and transmission ways.

In Botucatu region, São Paulo state, Brazil, a prevalence of $7.8 \%(16 / 204)$ for leptospirosis was found in hematophagous bats (Desmodus rotundus), which demonstrates the possible importance of these animals as Leptospira spp. reservoirs (18). Furthermore, one case of human leptospirosis was registered having a bat as possible source of infection in Chicago, USA (58).

In a study conducted with 343 bats captured in different areas in São Paulo city, only six were positive by PCR to pathogenic leptospires using renal tissue samples and none was reacted, which suggests that bats may not act as reservoirs in São Paulo city (59).

\section{Recreational Aspect}

International travels are becoming more frequent throughout the globe and it is believed that there will be about 1.6 billion international travels by 2020. Moreover, an increasing number of travelers is engaged in adventure travel. Travelers participating in athletic and adventure activities may be exposed to various infectious agents often uncommon to physicians in their homeland and that may demand immediate attention due to possible morbidity and even fatal outcome (25).

An increase in the number of travelers exposed to leptospiral infection during recreational activities has been observed throughout the globe (60). In the United Kingdom, more than half of the leptospirosis cases diagnosed are acquired abroad, mostly from tropical and subtropical destinations. In Israel, 42\% of all leptospiral infections from 2002 to 2008 were diagnosed in returned travelers, most coming back from Southeast Asia. In Germany, international travel is the most important risk factor for leptospirosis, accounting for $16 \%$ of all cases (22).

Fever is one of the most common presentations of leptospirosis in returned travelers. Differential diagnosis must include malaria, respiratory illness, 
diarrhea and dengue fever (22). Leptospirosis diagnosis is complex and in some cases of affected travelers, mainly those who came from endemic tropical regions, where there is a great variety of serovars distinct from those that occur in their home country, the diagnosis is impracticable (60). Most leptospirosis cases acquired during international travels are originated in Southeast Asia, Caribbean Islands and Central and South Americas (25).

Swimming in contaminated water has been reported as a risk factor for infection, especially when ingestion of water occurs $(33,61)$. Furthermore, prolonged immersion can make the skin more penetrable and allow the entrance of leptospires (15).

Leptospires survive long periods in humid environments and high temperatures (23). Higher temperatures may reduce water availability by evaporation and at the same time encourage water-based activities for humans and animals (swimming, bathing, drinking), thereby promoting contact between humans, livestock, pets and wildlife through more intense sharing of water sources (62).

Several leptospirosis outbreaks worldwide were related to recreational activities (63-65). In 1987, in São José dos Campos, São Paulo state, Brazil, an outbreak of human leptospirosis was associated with water activities. Sixty persons who were participating in a club party were using a running water pool formed by a stream. Of them, 22 got sick and were suspected of hepatitis and meningitis. Leptospirosis diagnosis was positive to Pomona serovar, which reservoirs are usually swine. Epidemiological and laboratorial data suggest that the source of the outbreak was water from the swimming pool contaminated with swine manure, since about $1.5 \mathrm{~km}$ from the club the stream passed through a sty (66).

Numerous cases of leptospirosis have been reported among adventure travelers and athletes participating in freshwater sports and probably most of them remain unrecognized $(61,63$, 67-69). Mainly due to nonspecific symptoms commonly encountered in leptospirosis, the lack of awareness of this illness as a cause of fever among returned travelers and the unavailability of diagnosis tests. Given the increasing popularity of travels and ecotourism mostly in tropical areas, it appears that the incidence of leptospirosis among travelers will increase. Travel-acquired leptospirosis has been associated with freshwater swimming, rafting, kayaking, canoeing, fishing, hunting and trail biking (25).

In 1998, in Springfield, Illinois, USA, leptospirosis cases were reported among triathlon participants. Three athletes developed symptoms followed by leptospirosis confirmation. The 834 participants were contacted by phone and $12 \%$ of them developed the same symptoms. Of the 474 tested, $11 \%$ were seropositive. Then, 27 samples from the lake water where the competition occurred were analyzed, but only one was positive by PCR. Moreover, renal samples from wild animals - including raccoons and deer were also positive by PCR (61).

After a triathlon proof near Heidelberg and Neckar River, in Germany, 142 participants out of 507 were contacted and five developed leptospirosis. In this case, open wounds were considered risk factors for the infection. High rainfall had occurred in the region before the proof, which possibly increased leptospiric contamination in Neckar River. This was the first leptospirosis outbreak in sportive competitions in Germany. Although sporadic cases of leptospirosis occur in European countries, they are more frequent in tropical climate countries (64).

Public health authorities should keep in mind the potential of leptospirosis outbreaks in the course of freshwater athletic events mainly following heavy rainfall and floods, as well as provide information about the disease and implement systemic surveillance for early diagnosis and control (25).

Adventure travelers, athletes participating in freshwater sports, military recruits traveling to leptospirosis endemic areas should be informed about the risk of acquiring the infection and be aware to wear protective waterproof clothes and boots, to avoid submersion and consumption of river water and to cover skin lesions with waterproof dressings to minimize exposure to contaminated environments. It is important to verify before traveling the occurrence of floods and heavy rainfall in the destiny (25).

Vaccination could be an important tool to prevent leptospirosis outbreaks among travelers. However, in view of the numerous pathogenic Leptospira serovars, a specific vaccine remains impracticable. 


\section{CONCLUDING REMARKS}

Several animal species are susceptible to leptospirosis including humans. This infection affects all population, although outbreaks are related to education level, sanitary conditions, housing and reservoir presence.

In developed countries, leptospirosis occur mainly due to occupational exposition, travels to endemic areas, recreational activities or domestic and wild animals importation, while in developing countries it occurs due to daily activities, high population density, low level of basic sanitation and climate conditions (70).

Leptospirosis is likely to be an underdiagnosed cause of fever in adventure seekers and returned travelers. This important zoonosis should be considered as a differential diagnosis of fever symptoms, particularly in those who have travelled to risky areas or participated in high-risk activities. Early recognition, diagnosis and treatment will reduce the incidence of the severe form of the disease and deaths (22).

As for all infectious diseases, leptospirosis occurrence is connected to the presence of the agent, reservoir and susceptible hosts. Due to the emergence of leptospirosis - dissemination of the pathogen given human impact on nature - alterations in climate, environment and animal populations, leptospirosis is a constant concern to public health authorities making its prevention and control important tools to diminish the number of outbreaks.

\section{COPYRIGHT}

(C) CEVAP 2011

\section{SUBMISSION STATUS}

Received: December 9, 2010.

Accepted: December 15, 2010.

Abstract published online: January 25, 2011.

Full paper published online: May 31, 2011.

\section{CONFLICTS OF INTEREST}

There is no conflict.

\section{FINANCIAL SOURCE}

The State of São Paulo Research Foundation (FAPESP) provided the research fellowship for Leila Ullmann.

\section{CORRESPONDENCE TO}

HELIO LANGONI, Departamento de Higiene Veterinária e Saúde Pública, Faculdade de Medicina Veterinária e Zootecnia, UNESP, Distrito de Rubião Junior, s/n, Botucatu, SP, 18616-970, Brasil. Phone: +55 14 3811-6270, ext. 24. Fax+55 1438116075 . Email: hlangoni@fmvz. unesp.br.

\section{REFERENCES}

1. AVMA. One Health Initiative Task Force. One health: a new professional imperative. Schaumburg: American Veterinary Medical Association; 2008. $76 \mathrm{p}$.

2. Aguirre AA, Tabor GM. Global factors driving emerging infectious diseases. Ann N Y Acad Sci. 2008;1149(1):1-3.

3. Adler B, de la Peña Moctezuma A. Leptospira and leptospirosis. Vet Microbiol. 2010;140(3-4):28796.

4. Langoni H. Leptospirose: aspectos de saúde animal e de saúde pública. Rev Educ Contin. 1999;2(2):52-8.

5. Bharadwaj R. Leptospirosis - a reemerging disease? Indian J Med Res. 2004; 120(3):136-8.

6. Bourhy P, Collet L, Clément S, Huerre M, Ave $\mathrm{P}$, Giry $\mathrm{C}$, et al. Isolation and characterization of new Leptospira genotypes from patients in Mayotte (Indian Ocean). PLoS Negl Trop Dis. 2010;4(6):724.

7. Brasil, Ministério da Saúde. Casos confirmados de Leptospirose. Brasil, Grandes Regiões e Unidades Federadas 1997 a 2009. Brasília: Ministério da Saúde, SINAN/SVS/MS; 2010.

8. McBride AJ, Athanazio DA, Reis MG, Ko AI. Leptospirosis. Curr Opin Infect Dis. 2005;18(1):376-86.

9. Gouveia EL, Metcalfe J, de Carvalho AL, Aires TS, Villalobos-Bisneto JC, Queiroz A, et al. Leptospirosis-associated severe pulmonary hemorrhagic syndrome, Salvador, Brazil. Emerg Infect Dis. 2008;14(3):505-8.

10. Abela-Ridder B, Sikkema R, Hartskeerl RA. Estimating the burden of human leptospirosis. Intern J Antimicrob Agents. 2010;36 Suppl 1:5-7.

11. Levett PN. Leptospirosis. Clin Microbiol Rev. 2001;14(2):296-326.

12. Ko AI, Galvão Reis $M$, Ribeiro Dourado CM, Johnson WD Jr, Riley LW. Urban epidemic of severe leptospirosis in Brazil. Salvador Leptospirosis Study Group. Lancet. 1999;354(9181):820-5.

13. Bharti AR, Nally JE, Ricaldi JN, Mathias MA, DIAZ MM, Lovett MA, et al. Leptospirosis: a 
zoonotic disease of global importance. Lancet Infect Dis. 2003;3(12):757-71.

14. Sharma S, Vijayachari P, Sugunan AP, Sehgal SC. Leptospiral carrier state and seroprevalence among animal population - a cross-sectional sample survey in Andamana and Nicobar Islands. Epidemiol Infect. 2003;131(2):985-9.

15. Faine S, Adler B, Boein C, Perolat P. Leptospira and leptospirosis. 2nd ed. Melbourne: Med Sci; 2000. 272 p.

16. Ullmann LS, Hoffmann J, Mores W, Cubas ZS, Santos LC, Silva RC, et al. Prevalence of Leptospira interrogans antibodies in captive wildcats of Southwestern Brazil. In: 31ํㅡ Congresso da Sociedade de Zoológicos do Brasil, 14 Congresso da Associação Latinoamericana de Parques Zoológicos e Aquários e do $16^{0}$ Encontro da Associação Brasileira de Veterinários de Animais Selvagens, São Paulo; 2007.

17. da Silva RC, Zetun CB, Bosco Sde M, Bagagli E, Rosa PS, Langoni H. Toxoplasma gondii and Leptospira spp. infection in free-ranging armadillos. Vet Parasitol. 2008;157(3-4):291-3.

18. Zetun CB, Hoffmann JL, Silva RC, Souza LC, Langoni H. Leptospira spp. and Toxoplasma gondii antibodies in vampire bats (Desmodus rotundus) in Botucatu region, SP, Brazil. J Venom Anim Toxins incl Trop Dis. 2009;15(3):546-52.

19. Langoni H, Kawaguchi MF, Oshika JC, Da Silva RC, Teixeira CR. Leptospira spp. antibodies in captive coatis (Nasua nasua Storr, 1780) (Carnivora: Procyonidae). J Venom Anim Toxins incl Trop Dis. 2009;15(4):762-7.

20. Fornazari F, Camossi LG, Silva RC, Guazelli A, Ribeiro MG, Langoni H. Leptospiral antibodies in wild boars (Sus scrofa) bred in Brazil. J Venom Anim Toxins incl Trop Dis. 2011:17(1):94-7.

21. Pappas G, Papadimitriou P, Siozopoulou V, Christou L, Akritidis N. The globalization of leptospirosis: worldwide incidence trends. Inter J Infect Dis. 2008; 12(4):351-7.

22. Lau C, Smythe L, Weinstein P. Leptospirosis: an emerging disease in travellers. Travel Med Infect Dis. 2010;8(1):33-9.

23. Lau CL, Smythe LD, Craig SB, Weinstein P. Climate change, flooding, urbanisation and leptospirosis: fuelling the fire? Trans R Soc Trop Med Hyg. 2010; 104(10):631-8.

24. Sugunan AP, Vijayachari P, Sharma S, Roy S, Manickam P, Natarajaseenivasan K. Risk factors associated with leptospirosis during an outbreak in Middle Andaman, India. Indian J Med Res. 2009;130(1):67-73.

25. Pavli A, Maltezou HC. Travel-acquired leptospirosis. J Travel Med. 2008;15(6):447-53.

26. Jansen A, Schöneberg I, Frank C, Alpers K,
Schneider T, Stark K. Leptospirosis in Germany, 1962-2003. Emerg Infect Dis. 2005;11(7):104854.

27. Senior K. Climate change and infectious disease: a dangerous liaison. Lancet Infect Dis. 2008;8(2):92-3.

28. Dias JP, Teixeira MG, Costa MC, Mendes CM, Guimarães P, Reis MG, et al. Factors associated with Leptospira sp. infection in a large urban center in Northeastern Brazil. Rev Soc Bras Med Trop. 2007;40(5):499-504.

29. Tiwari RR. Occupational health hazards in sewage and sanitary workers. Indian J Occupational Environmen Med. 2008;12(3):112-5.

30. Swapna RN, Tuteja U, Nair L, Sudarsana J. Seroprevalence of leptospirosis in high risk groups in Calicut, North Kerala, India. Indian J Medical Microbiol. 2006; 24(4):349-52.

31. Almeida LP, Martins LFS, Brod CS, Germano PML. Serological survey of leptospirosis among environmental sanitation workers in an urban locality in Southern Brazil. Rev Saúde Públ. 1994;28(1):76-81.

32. Natarajaseenivasan K, Boopalan M, Selvanayaki K, Suresh SR, Ratnam S. Leptospirosis among rice mill workers of Salem, South India. Jpn J Infect Dis. 2002; 55(5):170-3.

33. Hadad E, Pirogovsky A, Bartal C, Gilad J, Barnea A, Yitzhaki S, et al. An outbreak of leptospirosis among Israeli troops near the Jordan River. Am J Trop Med Hyg. 2006;74(1):127-131.

34. Benschop J, Heuer C, Jaros P, Collins-Emerson J, Midwinter A, Wilson P. Sero-prevalence of leptospirosis in workers at a New Zealand slaughterhouse. N Z Med J. 2009;122(1307):3947.

35. Desai S, van Treeck U, Lierz M, Espelage W, Zota L, Sarbu A, et al. Resurgence of field fever in a temperate country: an epidemic of leptospirosis among seasonal strawberryharvesters in Germany in 2007. Clin Infect Dis. 2009;48(15):691-7.

36. Herrmann-Storck C, Postic D, Lamaury I, Perez JM. Changes in epidemiology of leptospirosis in 2003-2004, a two El Niño Southern oscillation period, Guadalupe archipelago, French West Indies. Epidemiol Infect. 2008;136(10):1407-15.

37. Langoni H, Vasconcelos CGC, Nitsche MJT, Olbrich SRLR, Carvalho LR, Silva RC. Fatores de risco para zoonoses em alunos do curso de medicina veterinária, residentes e pósgraduandos. Arq Ciênc Vet Zool UNIPAR. 2009;12(2):115-21.

38. Langoni H, El Hage SS, Peruca LCB, Lucheis SB, Deffune E. Aglutininas anti-leptospiras em doadores de sangue. Vet Zootec. 2010;17(1):7984 . 
39. McMichael AJ, Woodruff RE, Hales S. Climate change and human health: present and future risks. Lancet. 2006;367(8513):859-69.

40. Patz JA, Kovats RS. Hotspots in climate change and human health. Br Med J. 325(7372):1094-8.

41. Tassinari WS, Pellegrini DC, Sa CB, Reis RB, Ko AI, Carvalho MS. Detection and modelling of case clusters for urban leptospirosis. Trop Med Int Health. 2008;103(4):503-12.

42. Cook AG, Watson J, Van Buynder PG, Robertson A, Weinstein $P$. $10^{\text {th }}$ anniversary review: natural disasters and their long-term impacts on the health of communities. J Environ Monit. 2008;10(2):167-75.

43. Sarkar U, Nascimento SF, Barbosa R, Martins R, Nuevo H, Kalofonos I, et al. Population-based case-control investigation of risk factors for leptospirosis during an urban epidemic. Am J Trop Med Hyg. 2002;66(5):605-10.

44. de Faria MT, Calderwood MS, Athanazio DA, McBride AJ, Hartskeerl RA, Pereira MM, et al. Carriage of Leptospira interrogans among domestic rats from an urban setting highly endemic for leptospirosis in Brazil. Acta Trop. 2008;108(1):1-5.

45. Herrmann-Storck C, Brioudes A, Quirin R, Deloumeaux J, Lamaury I, Nicolas $M$, et al. Retrospective review of leptospirosis in Guadalupe, French West Indies 1994-2001. West Indian Med J. 2005;54(1):42-6.

46. Reis RB, Ribeiro GS, Felzemburgh RD, Santana FS, Mohr S, Melendez AX, et al. Impact of environment and social gradient on Leptospira infection in urban slums. PLoS Negl Trop Dis. 2008;2(4):228.

47. Millán J, Candela MG, López-Bao JV, Pereira M, Jiménez MA, León-Viscaíno L. Leptospirosis in wild and domestic carnivores in natural areas in Andalusia, Spain. Vector Borne Zoonotic Dis. 2009; 9(5):549-54.

48. Bunnel JE, Hice CL, Watts DM, Montrueil V, Tesh RB, Vinetz JM. Detection of pathogenic Leptospira spp. infections among mammals captured in the Peruvian Amazon basin region. Am J Trop Med Hyg. 2000;63(5-6):255-8.

49. Richardson DJ, Gauthier JL. A serosurvey of leptospirosisin Connecticut peridomestic wildlife. Vector Borne Zoonotic Dis. 2003;3(4):187-93.

50. Mathias LA, Girio RJ, Duarte JM. Serosurvey for antibodies against Brucella abortus and Leptospira interrogans in pampas deer from Brazil. J Wildl Dis. 1999;35(1):112-4.

51. Koizumi N, Muto M, Yamada A, Watanabe H. Prevalence of Leptospira spp. in the kidneys of wild boars and deer in Japan. J Vet Med Sci. 2009;71(6):797-9.
52. Espí A, Prieto JM, Alzaga V. Leptospiral antibodies in Iberian red deer (Cervus elaphus hispanicus), fallow deer (Dama dama) and European wild boar (Sus scrofa) in Asturias, Northern Spain. Vet J. 2010;183(2):226-7.

53. Jansen A, Luge E, Guerra B, Wittschen P, Gruber $\mathrm{AD}$, Loddenkemper $\mathrm{C}$, et al. Leptospirosis in urban wild boars, Berlin, Germany. Emerg Infect Dis. 2007; 13(5):739-42.

54. Roberts MW, Smythe L, Dohnt M, Symonds M, Slack A. Serologic-based investigation of leptospirosis in a population of free-ranging Eastern grey kangaroos (Macropus giganteus) indicating the presence of Leptospira weilii serovar Topaz. J Wildl Dis. 2010;46(2):563-9.

55. Marvulo MFV, Silva JCR, Ferreira PM, Morais ZM, Moreno AM, Doto DS, et al. Experimental leptospirosis in capybaras (Hydrochaeris hydrochaeris) infected with Leptospira interrogans serovar Pomona. J Zoo Wildl Med. 2009;40(4):726-30.

56. Kuribara YI, Langoni H, Cabral KG, Baldini S, Silva AV, Neto PBS. Pesquisa de aglutininas anti-leptospiras em capivaras (Hidrochaeris hidrochaeris). In: 24ํㅡㄹ Congresso Brasileiro de Medicina Veterinária, 1996, Goiânia. Anais... Goiânia; 1996. 233 p.

57. Szonyi B, Agudelo-Flórez P, Ramírez M, Moreno N, Ko AI. An outbreak of severe leptospirosis in capuchin(Cebus) monkeys. Vet J. 2011;188(2)2379.

58. Vashi NA, Reddy P, Wayne DB, Sabin B. Batassociated leptospirosis. J Gen Intern Med. 2009;25(2):162-4.

59. Bessa TAF, Spichler A, Chapola EGB, Husch AC, Almeida MF, Sodré MM, et al. The contribution of bats to leptospirosis transmission in São Paulo City, Brazil. Am J Trop Med Hyg. 2010;82(2):3157.

60. Monahan AM, Miller IS, Nally JE. Leptospirosis: risks during recreational activities. J Appl Microbiol. 2009;107(3):707-16.

61. Morgan J, Bornstein Sl, Karpati AM, Bruce M, Bolin CA, et al. Outbreak of leptospirosis among triathlon participants and community residents in Springfield, Illinois, 1998. Clin Infect Dis. 2002;34(12):1593-9.

62. Dufour B, Moutou F, Hattenberger AM, Rodhain F. Global change: impact, management, risk approach and health measures - the case of Europe. Rev Sci Tech. 2008;27(2):529-50.

63. Narita M, Fujitani S, Haake DA, Paterson DL. Leptospirosis after recreational exposure to water in the Yaeyama islands, Japan. Am J Trop Med Hyg. 2005; 73(4):652-6.

64. Brockmann S, Piechotowski I, Bock-Hensely 
O, Winter C, Oehme R, Zimmermann S, et al. Outbreak of leptospirosis among triathlon participants in Germany, 2006. BMC Infect Dis. 2010;10(1):91.

65. Leshem E, Segal G, Barnea A, Yitzhaki S, Ostfeld I, Pitlik S, Schwartz E. Travel-related leptospirosis in Israel: a nationwide study. Am J Trop Med Hyg. 2010;82(3):459-63.

66. Lima SC, Sakata EE, Santo CER, Yasuda PH, Stiliano SV, Ribeiro FA. Surto de leptospirose humana por atividade recreacional no município de São José dos Campos, São Paulo: estudo soroepidemiológico. Rev Inst Med Trop São Paulo. 1990;32(6):474-9.
67. Shaw RD. Kayaking as a risk factor for leptospirosis. Mo Med. 1992;89(6):354-7.

68. Sevjar J, Bancroft E, Winthrop K, Bettinger J, Bajani M, Bragg S, et al. Leptospirosis in "ecochallenge" athletes, Malaysian Borneo, 2000. Emerg Infect Dis. 2003;9(6):702-7.

69. Koay TK, Nirmal S, Noitie L, Tan E. An epidemiological investigation of an outbreak of leptospirosis associated with swimming, Beaufort Sabah. Med J Malaysia. 2004;59(4):455-9.

70. Victoriano AFB, Smythe LD, Gloriani-Barzaga N, Cavinta LL, Kasai T, Limpakarnjanarat K. Leptospirosis in the Asia Pacific region. BCM Infect Dis. 2009; 9(1):147. 